\title{
Synthesis of Carbon Nanotubes from Catalytic Decomposition of $\mathrm{C}_{2} \mathrm{H}_{2}$ th rough $\mathrm{Pd} / \mathrm{Al}_{2} \mathrm{O}_{3}$ Catalysts
}

\author{
Ju Tack Han, Ja Hee Woo, Hae Sic Kim, and Jong Gi Jee \\ Department of Chemistr, Kungpook National Iniversit, Daegu 702-701. Korea \\ Received Julv 21, 2003
}

\begin{abstract}
CNTs have been sy'nthesized by cataly'tic $\mathrm{C}_{2} \mathrm{H}_{2}$ decomposition through $\mathrm{Pd}_{2} / \mathrm{Al}_{2} \mathrm{O}_{3}$ at low temperature. The CNTs were grown to a length of about $10 \mu \mathrm{m}$ and diameter $150-200 \mathrm{~nm}$ with multiwalled structure. Pd catalysts have two major roles: one is the active cataly'st for $\mathrm{C}_{2} \mathrm{H}_{2}$ decomposition. the other is a nucleation site of CNT's growth.
\end{abstract}

Key Words : Carbon nanotubes, $\mathrm{C}_{2} \mathrm{H}_{2}, \mathrm{Pd}_{\mathrm{Al}} \mathrm{O}_{3}$. $\mathrm{CVD}$, Decomposition

\section{Introduction}

Recently: carbon nanotubes (CNTs) have attracted a great deal of attention with nano materials consisting of particles with diameter less than $100 \mathrm{~nm}$ as an essential component of nanotechnology. .: $^{2}$ Since CNTs were first observed in 1991. ${ }^{3}$ CNTs have been studied for many applications. such as electronics. mechanics. display and energy and hydrogen storage because of their particular mechanical and electronic properties.

CNTs can be produced by arc discharge ${ }^{+}$laser-ablation. ${ }^{5}$ or by plasma-enhanced chemical vapor deposition (PECVD) ${ }^{6}$ or thermal chemical vapor deposition. ${ }^{7}$ A technique of synthesis by catalytic decomposition of hydrocarbons was recently reported in which hydrocarbons are decomposed directly into hydrogen and carbon. CNTs were synthesized by decomposition of $\mathrm{C}_{2} \mathrm{H}_{2}$ using $\mathrm{Fe}-\mathrm{Mo}$ catalysts at $950^{\circ} \mathrm{C}{ }^{8}$ Additionally: Youngdan Li et al. reported the production of hydrogen and nanocarbon by decomposition of methane on a nickel-based catalyst. ${ }^{5}$ In that method. it was difficult to have high productivity at low temperature and to separate metal particles from CNTs. In addition. iron. nickel and cobalt were usually used as the nucleation site of CNT's growth.

Generally catalytic decomposition of hydrocarbons is the method for producing a pure hydrogen stream from natural gas ${ }^{\text {li) }}$ Hydrocarbons are cracked directly into hỵdrogen and carbon. Catalysts used in that experiment promote the complete decomposition of hydrocarbons and improve the energy effciency of the process. ${ }^{11}$ Most catalysts for decomposition of hydrocabons were noble metals. Among the noble metal cataly'sts. supported palladium has been recognized as the most active catalyst for methane combustion with thermal stability. 12.13

In this paper we use CNT synthesis from catalytic decomposition of $\mathrm{C}_{2} \mathrm{H}_{2}$ through $\mathrm{Pd} / \mathrm{Al}_{2} \mathrm{O}_{3}$ cataly'st.

${ }^{*}$ Corresponding author. Tel.: +82-53-584-9302, Fax: $+82-53-$ 584-9309, e-nail: jthan adni.or.ks

\section{Experimental Procedures}

Preparation of the catalyst. $\mathrm{Pd}\left(\mathrm{NO}_{3}\right)_{2} 6 \mathrm{H}_{2} \mathrm{O}$ was dissolved in distilled water and alumina granuals ( $3 \mathrm{~mm}$ dia.) added to the aqueous solution of a palladium nitrate.

The loaded supports were dewatered and dried at $120^{\circ} \mathrm{C}$ for $6 \mathrm{hr}$. The supported catalysts were calcined at $400^{\circ} \mathrm{C}$ for $3 \mathrm{hr}$ with flowing $\mathrm{O}_{2}$ gas in order to eliminate impurities adsorbed on supported catalysts and finally the sample of cataly'st precursor was obtained.

Preparation of carbon nanotubes. Figure 1. shows a schematic diagram of the experimetal system. The reactor consists of a $30 \mathrm{~mm}$ o.d $\times 70 \mathrm{~cm}$ long quartz tube. The reactor was heated by an electrical tube furnace and was controlled to $\pm 1{ }^{\circ} \mathrm{C}$ by the temperature controller. To eliminate oxygen in $\mathrm{C}_{2} \mathrm{H}_{2}$ gases, the adsorbent was put on the front of quartz tube. The catalyst bed supported on stainless steel gauze was placed in the center of the furnace. In order to eliminate all chemisorbed water. catalysts were reduced in flowing $\mathrm{H}_{2}(50 \mathrm{~mL} / \mathrm{min})$ for $1 \mathrm{hr}$ at $650^{\circ} \mathrm{C}$.

The flow rate of gases was controlled by mass flow controllers (MFCs). Then $\mathrm{C}_{2} \mathrm{H}_{2}$ gas was introduced to the quartz tube with a flow rate of $30 \mathrm{sccm}$ for $20 \mathrm{~min}$ at $650^{\circ} \mathrm{C}$ and $950{ }^{\circ} \mathrm{C}$. Then the reactor was cooled to room temperature with flowing Argon gas.

The CNTs were examined by scanuing electron microscope (SEM) (Hitachi S-4300), themal analyzer (Rheometric Scientific STA1500), transmission electron microscopy (TEM) (JEOL JEM3010) and Raman spectrometer (Renishaw micro raman).

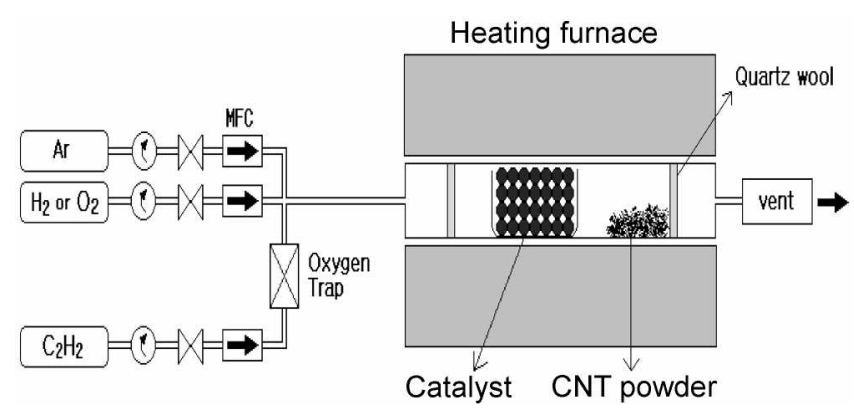

Figure 1. Experimental setup used for synthesis of CNTs 


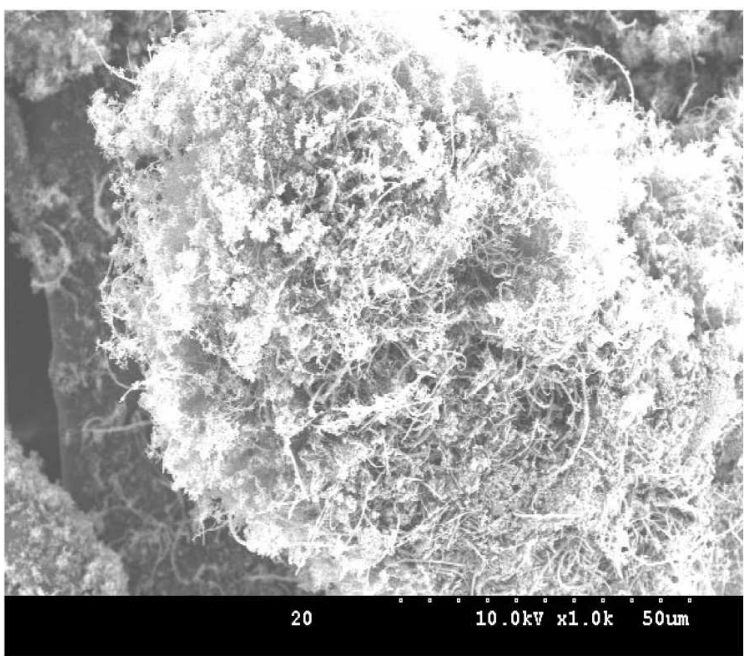

(A)

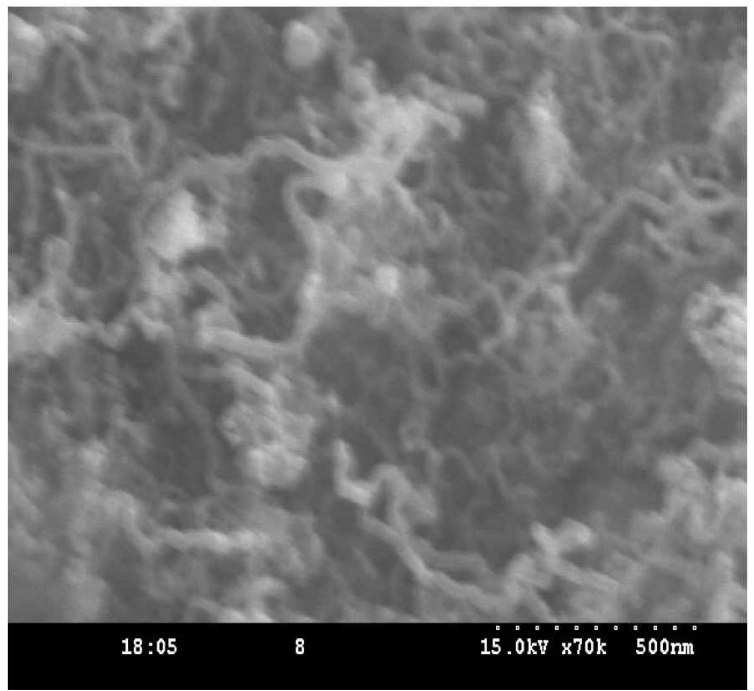

(B)

Figure 2. SEM inage of $\mathrm{CNT}$ s on $\mathrm{Pd} / \mathrm{Al}_{2} \mathrm{O}_{3}$ catalysts grown by decomposition of $\mathrm{C}_{2} \mathrm{H}_{2}$ at $650^{\circ} \mathrm{C}$, (b) Magnified view of CNTs which are in the range dia. 15-25 $\mathrm{nm}$.

\section{Results and Discussion}

CNTs were synthesized on $\mathrm{Pd} / \mathrm{Al}_{2} \mathrm{O}_{3}$ cataly st using $\mathrm{C}_{2} \mathrm{H}_{2}$ gas with flow rate of $30 \mathrm{sccm}$ for $20 \mathrm{~min}$ at $650{ }^{\circ} \mathrm{C}$. We found that CNTs had covered the entire heated section of the reactor as well as the $\mathrm{Pd} / \mathrm{Al}_{2} \mathrm{O}_{3}$ catalyst.

We checked the surface morphology of catalysts, as shown in Figure 2. The CNTs were fibrous and grown in a random direction on palladium catalysts. The diameter of CNTs was about 15-25 un.

Figure 3 . is a SEM image of CNT powder deposited on the inner surface of the quartz tube by decomposition of $\mathrm{C}_{3} \mathrm{H}_{2}$ gas with flow rate of $30 \mathrm{sccm}$ for $20 \mathrm{~min}$ through $\mathrm{Pd} / \mathrm{Al}_{2} \mathrm{O}_{3}$ cataly st at (a) $650^{\circ} \mathrm{C}$ and (b) $950^{\circ} \mathrm{C}$. CNT powder grown at $650^{\circ} \mathrm{C}$ shows a length of $10 \mu \mathrm{m}$ and dia. $150-200 \mathrm{~mm}$ with multiwalled structure, as shown in Figure t. The diameter of $\mathrm{CNT}$ powder is larger than that of $\mathrm{CNTs}$ on $\mathrm{Pd} / \mathrm{Al}_{2} \mathrm{O}_{3}$

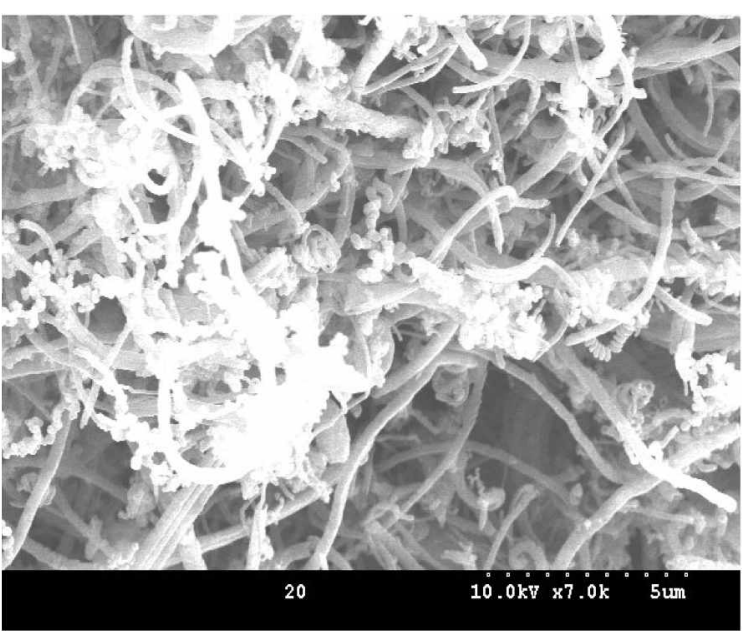

(A)

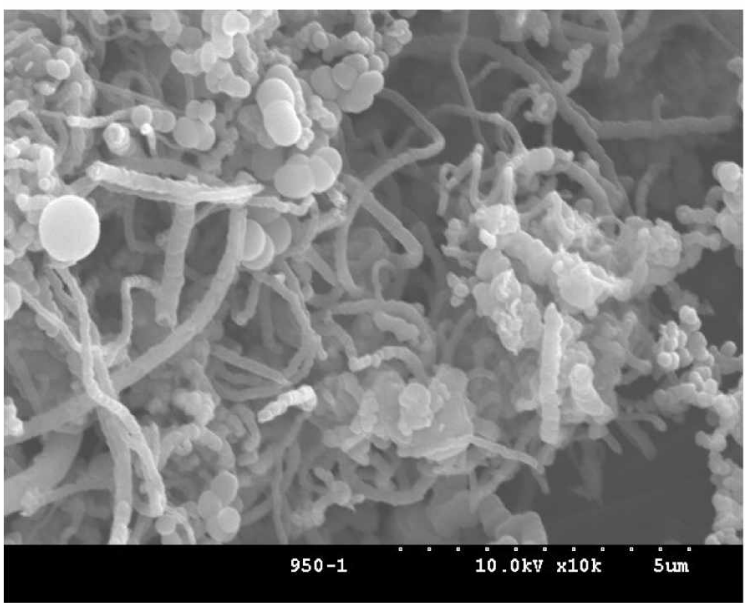

(B)

Figure 3. SEM image of CNT powder grown by decomposition of $\mathrm{C}_{2} \mathrm{H}_{2}$ through $\mathrm{Pd} / \mathrm{Al}_{2} \mathrm{O}_{3}$ catalyst at (a) $650{ }^{\circ} \mathrm{C}$, (b) 950 " $\mathrm{C}$.

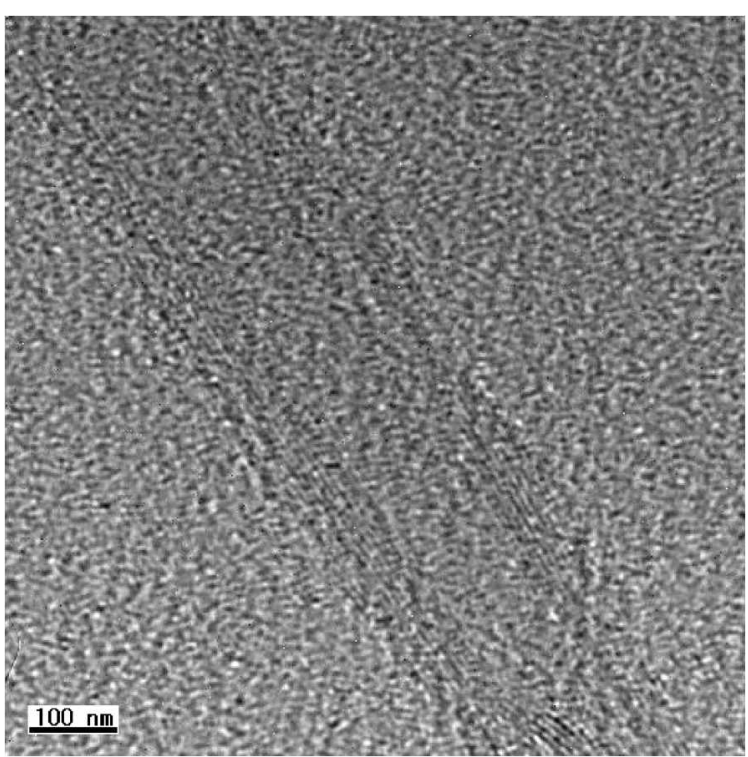

Figure 4. HRTEM image of CNT powder produced by decomposition of $\mathrm{C}_{2} \mathrm{H}_{2}$ through $\mathrm{P} d / \mathrm{Al}_{2} \mathrm{O}_{3}$ at $650^{\circ} \mathrm{C}$, which shows an inside hollow and multiwalled structure. 


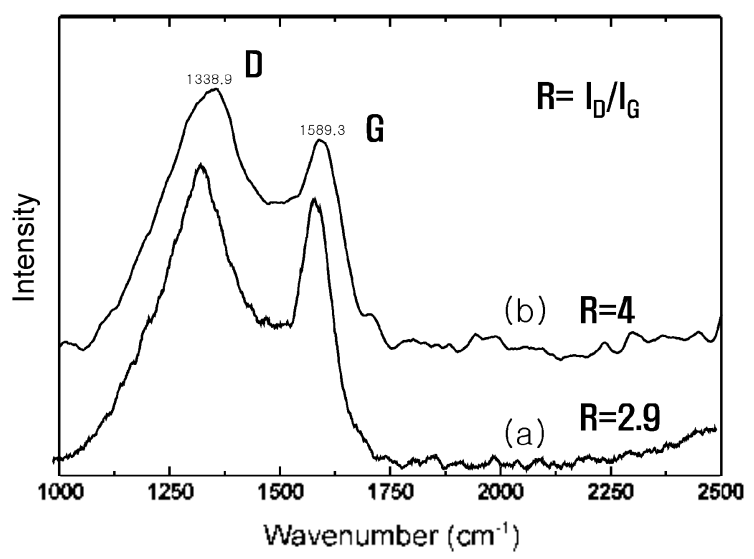

Figure 5. Raman spectrum of $\mathrm{C} N \mathrm{~N}$ powder produced by decomposition of $\mathrm{C}_{2} \mathrm{l}_{2}$ through $\mathrm{Pd} / \mathrm{A} \mathrm{I}_{2} \mathrm{O}_{3}$, catalyst at (a) 650 ' $\mathrm{C}$. (b) $950^{\circ} \mathrm{C}$.

catalyst. CNTs at $950{ }^{\circ} \mathrm{C}$ have more carbon defects (amorphous carbon, carbon fiber etc..) than at $650^{\circ} \mathrm{C}$.

Figure 5, shows the Raman spectrum of CNTs grown at (a) $650{ }^{\circ} \mathrm{C}$ and (b) $950^{\circ} \mathrm{C}$. The Raman-allowed (G) line at $1590 \mathrm{~cm}^{-1}$ has been assigned to the streching mode $\left(\Gamma_{2} \mathrm{~g}\right)$ of graphite. The disorder-induced (D) line at $1337 \mathrm{~cm}^{-1}$ indicates carbon defects. ${ }^{1 \cdot 1}$

In the Raman spectra we confirmed that the CNTs had crystalline structure and some carbon defects. The ratio of the integrated intensity of the $D$ line to the $G$ line $R=I_{V} / I_{\mathrm{G}}$ provides a sensitive characterization of the disorder in the sample. ${ }^{15}$ The peak intensity ratio, $\mathrm{R}$ at $650^{\circ} \mathrm{C}$ and $950^{\circ} \mathrm{C}$, have $2,9,4.0$ respectively. The peak intensity ratio of the $D$ to $\mathrm{G}$ bands increased with higher temperature, indicating that crystallinity of $\mathrm{CNT}$ s grown at $650^{\circ} \mathrm{C}$ is higher than that of $\mathrm{CNT}$ at $950^{\circ} \mathrm{C}$. This result agrees with Figure 3. This suggests that as pyrolysis of $\mathrm{C}_{2} \mathrm{H}_{2}$ at $950^{\circ} \mathrm{C}$ occurs not only on $\mathrm{Pd} / \mathrm{Al}_{2} \mathrm{O}_{3}$ but also itself $\mathrm{C}_{2} \mathrm{H}_{2}$ the CNTs on catalysts and carbon defects are formed.

rigure 6. shows the TGA graph of synthesized CNTs. Measurement was carried out in air, at a temperature range from $25^{\circ} \mathrm{C}$ to $900{ }^{\circ} \mathrm{C}$ and the heating rate was $5{ }^{\circ} \mathrm{C}$ per

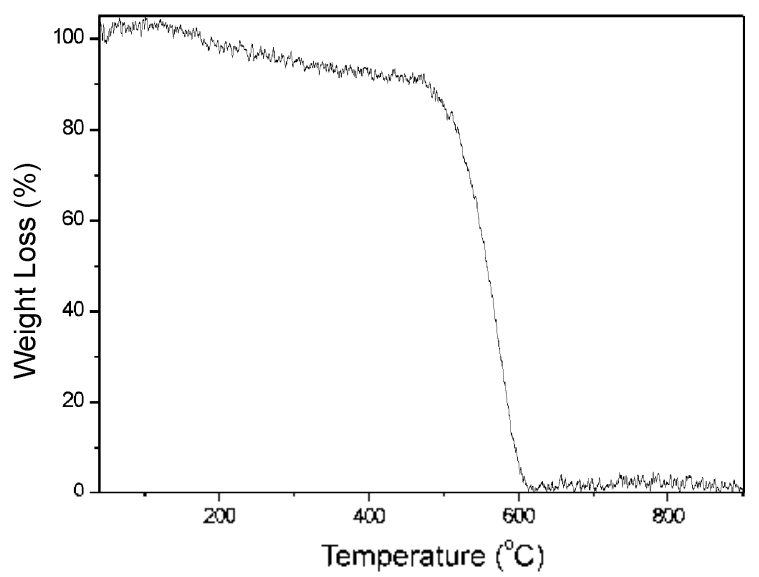

Figure 6. TG $\wedge$ data of weight loss for $\mathrm{C}$. $\mathrm{VI}$ powder grown at 650 "C. The CNTs start to gasify vertically at $470^{\circ} \mathrm{C}$. minute. In this figure, the initial burning temperature was about $150^{\circ} \mathrm{C}$. Weightloss started at $150^{\circ} \mathrm{C}$. Weight of CNTs reduced slowly from $150^{\circ} \mathrm{C}$ to $470^{\circ} \mathrm{C}$ and vertically after $470{ }^{\circ} \mathrm{C}$. The former area is a weight-loss of amorphous carbon and the latter is a weight-loss of CNTs. This result corresponds to the typical properties of CNTs, as previous reported. ${ }^{16}$ Weight-loss ended at $600{ }^{\circ} \mathrm{C}$ with a little metal.

We suggest that the $\mathrm{C}_{2} \mathrm{H}_{2}$ is thermally decomposed through $\mathrm{Pd} / \mathrm{Al}_{2} \mathrm{O}_{3}$ at low temperature.

$$
\mathrm{C}_{2} \mathrm{H}_{2} \rightarrow 2 \mathrm{C}(\mathrm{s})-\mathrm{H}_{2}
$$

The catalysis reaction occurs on the surface of $\mathrm{Pd}_{\mathrm{d}} \mathrm{Al}_{2} \mathrm{O}_{3}$. Solid carbons and hydrogens are formed through pyrolysis of $\mathrm{C}_{2} \mathrm{H}_{2}$. Solid carbons are adsorbed on Pd catalysts and dissolved into catalysts. Hence, CNTs are grown on the catalysts and are separated from the Pd catalyst.

The heat of adsorption and data of $\mathrm{C}-\mathrm{H}$ dissociation rate constant data at $550-8500^{\circ} \mathrm{C}$ on Pd catalysts are not known for the decomposition of $\mathrm{C}_{2} \mathrm{H}_{2}$ gases. However, Kesmodel et al. showed that chemisorbed acetylene at $300 \mathrm{~K}$ results in the formation of mainly ethylidyne, $\mathrm{C}-\mathrm{CH}_{3}$ and a small amount of residual acetylene. Delyydrogenation begins at around $400-500 \mathrm{~K}$, with formation of $\mathrm{CH}$ species. ${ }^{17}$ Naresh Shal et al, have reported hydrogen production from methane decomposition for Pd catalysts at $700{ }^{\circ} \mathrm{C} \cdot{ }^{18} \mathrm{Pd}$ was active catalyst for methane decomposition. Fiven a small amount of Pd yielded substantial hydrogen at lower temperature.

We demonstrate that $\mathrm{Pd}$ catalysts have an efficiency for decomposition of $\mathrm{C}_{2} \mathrm{H}_{2}$ at low temperature.

\section{Conclusions}

CNTs have been synthesized by $\mathrm{C}_{2} \mathrm{H}_{2}$ decomposition through $\mathrm{Pd} / \mathrm{Al}_{2} \mathrm{O}_{3}$ at $650^{\circ} \mathrm{C}$. The synthesized CNTs have a diameter in the range $150-200 \mathrm{~nm}$ with multiwalled structure. Finally, we suggest that Pd catalysts not only are active catalysts for $\mathrm{C}_{2} \mathrm{H}_{2}$ decomposition, but also nucleation sites of growth. When the temperature of decomposition is $950^{\circ} \mathrm{C}, \mathrm{CN}$ 's have more carbon defects than at $650^{\circ} \mathrm{C}$.

This approach can be easily applicable to massive production of CNT's at low temperature.

Acknowledgements. We acknowledge the support by Kyungpook National University Fund 1995 and Daegu City Government 2002 Nano project, and was also supported by Daesung Sanso Co., l.td.

\section{References}

1. I.ee. I. K.: Choi. S. M. Bull. Notean Chem. Soc. 2003. 24. 32.

2. Jung. O. J.: Kint. S. H.: Cheong. K. H.: Li. W. S.: Saha. I. Bull. Korean ('hem. Sor: 2003. 24. 49.

3. Iijima. S. Nature llondon 1991. 35\%. 56.

4. (ito., T.: Nikolatw, P.: Rinzler, A. G.: Tentanck. D.: Colbert. D. T.: Smalley. R. I.J. Plus. Chem. 1995. 99. 10694.

5. Yudasaka. M.: Komatsu. I.: Ichihashi. T.: Iijima. S. Chem. Phws. lett. 1997. 278.102 .

6. Ren. Z. F.: Huang. Z. P.: Xu. I. W.: Wang. J. H.: Bush. P.: Sicgel. M. P.: Provencio. P. N. Science 1998. 282. 11057. 
7. Ivanov, V: Fonseca. A.: Nagy. J. B.: Lucas. A.: Lambin. P.: Bernaerts. D.: Zhang. X. B. Carbon 1995. 33.1727.

8. Lvu, S. C. Liu, B. C.: Lee. T. J.: Liu, Z. Y: Yang C. W.: Park: C. Y: Lee, C. J. Chent Conmun 2003, 6.734.

9. Li, Y.: Chen. I.: Qin. Y: Chan, L. Energn \& Fitels American Chemical Society 2000. 14. 1188.

10. Ryu. C. K.: Wong. M.: Ryu. I. S.: Kang. S. K. Catahsis Today 1999. 47. 141

11. Hovos. L. I.: Paliaud. H.: Primet. M. Appl. Catal. 1992. A\$1, 227.

12. Steinberg, M. Cheng. M. J. Hydrogen Energy 1984, 14. 797.
13. Tuinstra. F.: Koenig. T. L. J. Chem. Phys. 1970. 53.1126.

14. Chent. X. H.: Chen. C. S.: Chen. Q.: Cheng. F. Q.: Zhang. G.: Chen. Z. Z. Mater Lett 2002. 57.734.

15. Al-Jishi, R.: Dresselhaus, G. Phos. Ren: 1982, B26, 4514.

16. Shi. S. J.: Lian. Y. F.: Liao, F. H.: Zhou. X. H.: Gu. Z. N.: Zhang. Y.: Iijinna. S. Solid State Conmm. 1999. 300. 2555.

17. Kesmodel. L. L.: Waddill. G. D.: Gates. T. A. Suff Sci. 1984. 138. 464.

18. Shah. N.; Panjala, D; Huftman, G. P. Energy \& Fitels Anerican Chentical Society 2001. 15. 1528. 